\title{
Life without Milk
}

Janis Latimore

200 5th Street PO Box 8116, Alexandria, VA., 22306, USA.

*Corresponding author: Janis Latimore, 200 5th Street PO Box 8116, Alexandria, VA, 22306, USA.

Received date: June 19, 2020; Accepted date: July 10, 2020; Published date: July $20,2020$.

Citation: Janis Latimore, (2020) Life without Milk. J. Nutrition and Food Processing, 3(2); DOI:10.31579/2637-8914/026

Copyright: (c) 2020 Janis Latimore, This is an open-access article distributed under the terms of the Creative Commons Attribution License, which permits unrestricted use, distribution, and reproduction in any medium, provided the original author and source are credited.

This op-ed article is a metaphor, bemoaning life without the cruelty, brutality, and murder of minorities by police. It indicates the similarities in not needing milk nor police when it is intolerant to survival.

Milk is an important nutrient, staple, and a source of calcium for the purpose of supplementing the health in children's development and for adults in need of additional, calcium-rich foods. Milk is known to build bone development and density.

Milk has a long history in the "western diet" (Dalsgaard, Bertram 2015) (standard American diet), as an important nutrient, representative as a valuable source for the human body. In validating food "intake biomarkers (a measurable substance in an organism whose presence is indicative of some phenomenon, such as disease, infection, or environmental exposure), milk becomes part of the human biofluid (a generic term for bio-organic fluid produced by an organism such as, serum, plasma, urine, saliva, and so on" (Dalsgaard, Bertram 2015).

We are taught by our parents and advised by natal-conscious doctors, that children cannot grow or maintain a healthy life as babies, pre-k, young adults or grown-ups, if we don't drink milk or have a diet of milk byproducts. But in 1972, early research found; "Negroes" (Paige, Bayless, Graham 1972), Asians, American Indians, Hispanic, South Americans and Black Heritage (American Family Physician, 2006), had trouble digesting an enzyme that breaks down the natural sugar in milk and the same intestinal intolerance arrives in significant numbers when this same group of people within the greater population are in the presence of police.

Lactose intolerance exist in a number of Black people and other people of color in general when milk is forced upon children and adults but it appears there is no "long-term biological effect" (Paige, 1972), on the development of healthy children if they do not have milk in their diet until they encounter police, as that nutritional value of milk or the profiling does not readily improve their well-being. Instead non-drinkers of milk (like myself), who have survived without milk or milk by-products; research has found that there is "no evidence that higher intakes of milk or calcium or greater numbers of police activity reduce but produce chokeholds, gunshots, imprisonment, and or oppression but do not indicate a reduced risk of osteoporotic fractures or safety to minority communities. Be mindful, milk does have beneficial value and police save lives and are often effective.
In conclusion, if we can live without the certain nutritional properties in milk, we can certainly live without the cruelties from police that have affected people of color throughout American History. Milk is necessary for the consumption of babies and mothers' milk will provide important antibodies for a child. As that child matures and become lactose intolerant and there are rumblings, stomach cramps, bloating, and then gas, the body can no longer digest nor live with milk. It is then removed from their diet. Milk does not mix well in minority communities. It does not digest where Black men drive, it does not compute where Black women sleep, it does not rationalize in the thought process when young Black men buy Skittles, jaywalk, jog, sell individual cigarettes, or when Black men are purchasing weapons in a Walmart and the cashier does not put that particular rifle in a gun bag. There is an expiration date on milk cartons. The usefulness of milk and police in American culture and the amount of power they are instilled must be immediately re-evaluated, reduced, reformed and in some instances removed and unfunded where Gestapo tactics, brutality, and murder have been the exception rather than the rule. COVID-19 and the illnesses ensued will end enough lives. Police murders should not be part of that equation. The density in bone development changes with milk just as pressure on policing will change the density and components as related to bringing about change.

\section{References}

1. American Family Physician, (Dec. 2006). Information from your family doctor: Lactose Intolerance: What you should know. Vol. 74, Issue11, p1927-1928, 2p. Database Education Source.

2. Feskanich, Diane, Willett, Walter, C., (June 1997). Milk, dietary calcium, and bone fractures in women: a 12-year prospective study. Vol. 87, p992, 6p. Academic Search Complete.

3. Hong, Zheng, Clausen, Morten, R., Dalsgaard, Trine, K., Bertram, Hanne, C., (2015). Metabolomics to Explore Impact of Dairy Intake. Vol. 7, Issue 6, p4875-4896, 22p. American Academic Search.

4. Paige, David, M., Bayless, Theodore, M., Graham, George G., (Nov. 1972). Vol. 62, Issue 11, p1486-1488, 3p; Database: Education Source. 